\title{
Patterns of plant invasions in China: Taxonomic, biogeographic, climatic approaches and anthropogenic effects
}

\author{
Shan-Huah Wu $\cdot$ Hao-Ting Sun $\cdot$ Yung-Ching Teng • \\ Marcel Rejmánek · Shu-Miaw Chaw • \\ T.-Y. Aleck Yang $\cdot$ Chang-Fu Hsieh
}

Received: 6 March 2009/ Accepted: 14 October 2009/Published online: 29 November 2009

(C) The Author(s) 2009. This article is published with open access at Springerlink.com

\begin{abstract}
This study was aimed to determine the patterns as well as the effects of biological, anthropogenic, and climatic factors on plant invasions in China. About 270 volumes of national and regional floras were employed to compile a naturalized flora of China. Habit, life form, origin, distribution, and uses of naturalized plants were also analyzed to determine patterns on invasion. Correlations between biological, anthropogenic and climatic parameters were estimated at province and regional scales. Naturalized species represent $1 \%$ of the flora of
\end{abstract}

Electronic supplementary material The online version of this article (doi:10.1007/s10530-009-9620-3) contains supplementary material, which is available to authorized users.

S.-H. Wu · C.-F. Hsieh

Institute of Ecology and Evolutionary Biology,

National Taiwan University, 1, Sec. 4, Roosevelt Rd.,

Taipei 106, Taiwan

e-mail: shwu2@ntu.edu.tw

H.-T. Sun

Department of Life Science, National Taiwan Normal

University, 88, Sec. 4, Dingchou Rd., Taipei 116, Taiwan

Y.-C. Teng

Biodiversity Association of Taiwan, 4F, 4-1,

Chuanchou St., Taipei 100, Taiwan

M. Rejmánek

Department of Ecology and Evolution, University

of California at Davis, One Shields Ave.,

Davis, CA 95616, USA
China. Asteraceae, Fabaceae, and Poaceae are the dominant families, but Euphorbiaceae and Cactaceae have the largest ratios of naturalized species to their global numbers. Oenothera, Euphorbia, and Crotalaria were the dominant genera. Around 50\% of exotic species were introduced intentionally for medicinal purposes. Most of the naturalized species originated in tropical America, followed by Asia and Europe. Number of naturalized species was significantly correlated to the number of native species/log area. The intensity of plant invasion showed a pattern along climate zones from mesic to xeric, declining with decreasing temperature and precipitation across the nation. Anthropogenic factor, such as distance of transportation, was significantly correlated to plant

\author{
S.-M. Chaw \\ Biodiversity Research Center, Academia Sinica, \\ 128, Sec. 2. Academy Rd., Taipei 115, Taiwan \\ T.-Y. A. Yang $(\bowtie)$ \\ Department of Botany, National Museum of Natural \\ Science, 1, Kuanchien Rd., Taichung 404, Taiwan \\ e-mail: aleck@nmns.edu.tw \\ T.-Y. A. Yang \\ Department of Life Science, National Chung Hsing \\ University, 250, Kuokuang Rd., Taichung 402, Taiwan
}


invasions at a regional scale. Although anthropogenic factors were largely responsible for creating opportunities for exotic species to spread and establish, the local biodiversity and climate factors were the major factors shaping the pattern of plant invasions in China. The warm regions, which are the hot spots of local biodiversity, and relatively developed areas of China, furthermore, require immediate attentions.

Keywords Anthropogenic factor .

Biodiversity · Biogeographic pattern .

China Climate $\cdot$ Plant invasion $\cdot$ Taxonomic pattern

\section{Introduction}

Plant invasions, accelerated and aggravated by international trade and tourism, especially in developing countries (Levin and D'Antonio 2003; Ruiz and Carlton 2003; Valladares-Padua 2006), have been considered to be one of the most important environmental issues of our time. Unfortunately, reports and studies on plant invasions are anecdotal or local in purview. China, the largest country in Asia and one of the most important industrial countries in the world, has been experiencing booming economic and domestic development in recent decades (Ding et al. 2008; Weber and Li 2008a, b). Although recent attention has been paid to the pattern of plant invasion in China, figures for less familiar invasive plants in China, compiled from the literature, number only 1-200 (Liu et al. 2006; Ding et al. 2008; Weber and Li 2008a, b). Compared to the area and diversity of habitats in China, these are not significant numbers. The knowledge of plant invasions and potential invaders is limited and far behind studies in neighboring areas such as Singapore (Corlett 1988), Japan (Enomoto 1999), Korea (Koh et al. 2000), and Taiwan (Wu et al. 2003; Wu et al. 2004a, b).

Datasets that present floristic status, biological attributes, geographical distribution, and usage information on exotic species have been shown to be very effective tools for discerning patterns of plant invasions and species invasiveness (Rejmánek and Richardson 1996; Daehler 2001; Pyšek et al. 2002; Lake and Leishman 2004; Pyšek et al. 2004; Wu et al. 2004a, b; Cadotte et al. 2006). For a region where the status and composition of invasive species are not definite, establishment of a database of naturalized species should be the first step toward approaching local plant invasions.

Albeit that not every naturalized species will become invasive, but all invasive species are naturalized first. Naturalized species can therefore be considered to be potential invaders for characterizing the pattern of plant invasions. A naturalized species is defined as an introduced (non-native, exotic) species, that can consistently reproduce and sustain populations over many generations without (or despite) direct intervention by humans (Richardson et al. 2000; Pyšek et al. 2002).

Habitat characteristics, such as local biodiversity, climate, and anthropogenic activities, as well as the uses of plants, may have a bearing on successful invasions and invasion patterns (Chytrý et al. 2008; Van der Wal et al. 2008). It has been shown that most of successful, established, invasive species were introduced intentionally as ornamentals, or for forage, medicine, and other purposes (Mack and Erneberg 2002; Mack 2003), while unintentional introductions usually occurred through contaminated fodder or crop seeds, footwear, packing materials, and ballast (Kloot 1987). Although contributions from the local economy and from anthropogenic activities have been studied, patterns of plant invasion along climatic gradients have not been documented. In consideration of the pools of species in different climate regions of the world and the length of the growing season, the intensity of plant invasions may vary in accordance with local biodiversity and climates. Comparisons of native and naturalized floras across different climate zones will contribute to generate better understandings of plant invasions.

International and domestic transportation, tourism, and cargo shipments across borders have been considered to be important vectors responsible for species introduction and exchange (Jenkins 1996; Williamson 1996; Shigesada and Kawasaki 1997; Dalmazzone 2000; McNeely 2000). Regardless of China's importance in the world's industrial capacity, the improved economy has accelerated domestic development of the public infrastructure, such as railroads, airports, harbors, and highways (Ding et al. 2008). Although there have been warnings of exponential growth in the invasions by alien species with the booming economy (Ding et al. 2008; Weber and Li 2008a, b), there is no evidence to back up such 
warnings. Since national statistical information is well assembled and released to the public, the effects of the local economy and anthropogenic activities on the naturalized flora and patterns of plant invasion can be readily assessed.

The main purpose of this study was to reveal patterns of plant invasions in China by identifying and analyzing the naturalized flora. This first list of naturalized species in China will serve as a foundation for future research on plant invasions. Based on this compilation, several basic questions can be addressed regarding naturalized alien species in China: (1) Is there a taxonomic pattern? (2) Are some life forms or habits overrepresented? (3) What is the nativity of the naturalized plants? (4) What are the modes of introduction? Furthermore, we also approximated the effects of local biodiversity, climate and anthropogenic activity on plant invasions. By understanding the patterns of plant naturalization in China, the only missing piece of the puzzle on plant invasions in eastern Asia, we hope to generate insightful perspectives and information for further regional studies.

\section{Materials and methods}

\section{Catalogue of naturalized species}

To compile a list of the naturalized flora, we reviewed 270 national, regional, and local floras as well as e-floras. Additionally, relevant articles in Chinese and English journals published before September 2008 were reviewed as well. Among these references, 172 books and numerous documents cited the naturalized status of the species compiled in Appendix. We employed the Flora of China as the major source of naturalized status. Hundred of volumes were therefore not listed as references. Each species designated as naturalized, escaped or persistent after cultivation, or invasive, was marked for further examination. Species introduced or cultivated without evidence of escaping were not considered. Additional information, such as life form, habit, use, and origin of these species, was carefully extracted from these references. The distribution of each species was presented by province, with the number of provinces used to indicate degree of invasiveness. Species mentioned in the literature as naturalized or escaped without documenting specimens or without further field evaluation were considered to be possibly naturalized and are listed separately.

\section{Analysis}

Information on the species nativity, life form (converted to Raunkiaer system (Mueller-Dombois and Ellenberg 1974), habit, year of first available record, mode or purposes of introduction, was used in the analyses. The list was organized by family and genera. The ratio of number of naturalized species per family and genus in China to the total number of species per family and genus worldwide (Mabberley 1997), excluding species of China, was used for comparison. For the purpose of introduction, all uses of a particular species were included. The total percentage therefore exceeded one hundred. Species without information on purpose of introduction were treated as purpose unknown. Because information on the native distribution of species provided in different references was not consistent, we grouped species by broad categories according to their biogeographical origins, such as Africa, America, Asia, Europe, and Eurasia (excl. southern Asia).

Parameters of local biodiversity, human activities and climatic factors in China were obtained to evaluate their effects on plant invasions. Number of native species per provinces was obtained from China biodiversity databases, and the numbers were divided by logarithmic area of respective provinces as the indicator of local biodiversity. Factors of human activities, including demography (population size), amount of freight movement (per 10 million tons/ kilometer), freight quantity (billion tons), total length of transportation (kilometers), area used for transportation $\left(\mathrm{km}^{2}\right)$, and international tourists (per million people) were obtained from the official website (http://www.stats.gov.cn) of the National Bureau of Statistics of China. Climatic factors, such as annual average temperature $\left({ }^{\circ} \mathrm{C}\right)$, annual lowest temperature $\left({ }^{\circ} \mathrm{C}\right)$, annual highest temperature $\left({ }^{\circ} \mathrm{C}\right)$, and annual average precipitation $(\mathrm{mm})$, were collected from the official website (http://www.cma.gov.cn) of the China Meteorological Administration. Temperature difference $\left({ }^{\circ} \mathrm{C}\right)$ was calculated by subtracting the lowest temperature from the highest temperature. To reveal the relationships between trends in plant invasions and 
climate, a map of the climatic zones of China on the official website of Ministry of Culture, P. R. China (http://www1.chinaculture.org/index.html) was utilized. Multiple regression analyses (SPSS 15 2006) were applied to evaluate the relationships between plant invasions and parameters of anthropogenic effects and climatic factors in China. Collinearity analysis and adjusted $R^{2}$ were applied.

To characterize patterns of plant invasion across the nation, two categories were employed, province and region according to data availability. Data from 26 provinces were compiled to estimate plant invasions at the province scale, the basic administrative unit that usually has comprehensive background information for analyses. However, in consideration of data availability and regional development policy, background information for six regions was collected for further analyses as well. The six regions are: North (Beijing, Tianjin, Hebei, Shanxi, and Nei Mongol), Northeast (Liaoning, Jilin, and Heilongjiang), East (Shanghai, Jiangsu, Zhejiang, Anhui, Fujian, Jiangxi, and Shandong), South Central (southeast china; Henan, Hubei, Hunan, Guangdong, Guangxi, and Hainan), Southwest (Chongqing, Sichuan, Guizhou, Yunnan, and Xizang), and Northwest (Shaanxi, Gansu, Qinghai, Ningxia, and Xinjiang). These regions are named by their locations in China and are combinations of neighboring provinces that have relatively similar environmental and economic conditions. To standardize the incidences of plant invasion for comparison, an index of number of casual and naturalized species/log (area of a particular region in $\mathrm{km}^{2}$; Vitousek et al. 1997) was utilized.

\section{Results}

Documented naturalized species represent about $1 \%$ of the flora of China: 420 species in 273 genera and 84 families (Table 1; Appendix). Among these species, $84 \%$ are dicotyledons, $15 \%$ are monocotyledons, and two species are ferns. Chamaephytes represents $46.7 \%$ of the naturalized flora, followed by therophytes $(28.5 \%)$, phanerophytes $(16 \%)$, hemicryptophytes $(6 \%)$, and cryptophytes $(2.4 \%)$. Among the families and genera of the naturalized flora, $10 \%$ of the families are new to China, while $52 \%$ of the genera are new to China. Twenty-one additional species were categorized as status unknown (Appendix (Electronic supplementary information)).

Asteraceae, Poaceae, and Fabaceae have many more naturalized species than other families. Of the remaining families (for example, Euphorbiaceae, Amaranthaceae, Brassicaceae, and Convolvulaceae) all have fewer than 20 naturalized species per family (Fig. 1a). About $50 \%$ of the families contribute only one species to the naturalized flora, while $75 \%$ of the genera are represented by a single naturalized species. Euphorbiaceae $(2.4 \%)$ and Cactaceae $(2 \%)$ have the largest percent of naturalized species in China to the global number of species in the family, followed by Caryophyllaceae $(0.57 \%)$, Convolvulaceae $(0.54 \%)$, Agavaceae $(0.5 \%)$, and Amaranthaceae $(0.45 \%$; Fig. 1$)$. Of these families with higher ratios, the Amaranthaceae have the most naturalized species (43), followed by the Euphorbiaceae (18) and Convolvulaceae (16), while Agavaceae has the fewest (8).
Table 1 Numerical summary of the naturalized flora in China

Numbers in parentheses indicate families and genera new to China, respectively

\begin{tabular}{lllll}
\hline & Pteridophyta & Angiosperm & Total \\
\cline { 3 - 4 } & & Dicotyledons & Monocotyledons & \\
\hline Family & 2 & $70(7)$ & $12(1)$ & $84(8)$ \\
Genus & 2 & $223(117)$ & $48(23)$ & $273(140)$ \\
Species & 2 & 355 & 65 & 420 \\
Chamaephyte & - & 168 & 31 & 199 \\
Cryptophyte & - & 6 & 4 & 10 \\
Hemicryptophyte & - & 10 & 14 & 24 \\
Phanerophyte & - & 65 & 1 & 66 \\
Therophyte & & 104 & 15 & 117 \\
\hline
\end{tabular}


Fig. 1 Taxonomic patterns of naturalized plants in China. a Top ten dominant families according to species number and ratio of number of naturalized species in China to global number of species per family. b Top ten dominant genera according to species number and ratio of number of naturalized species in China to global number of species per genera

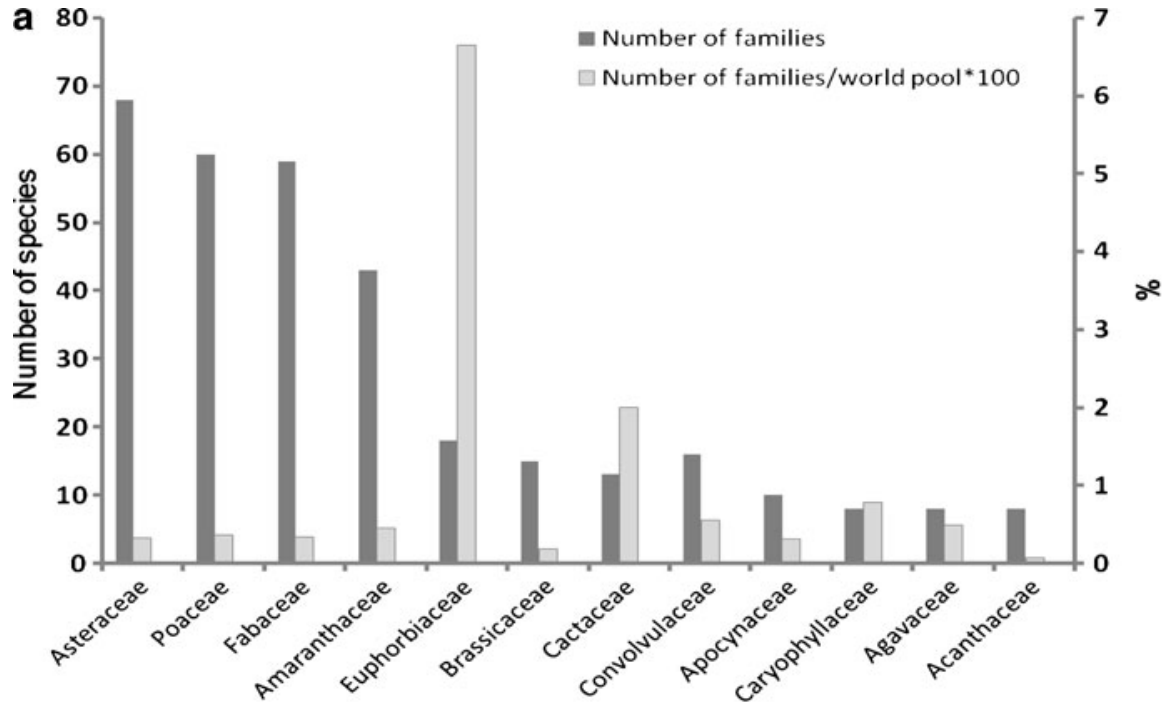

Family

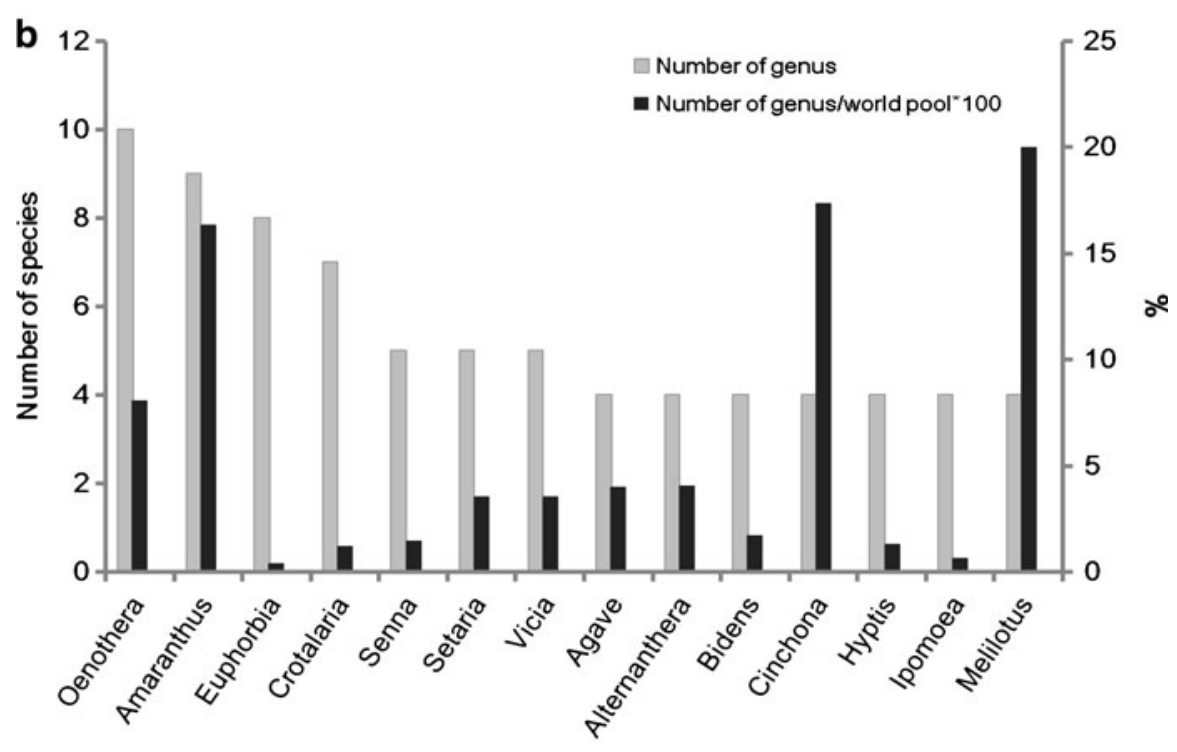

Dominant Genus
Oenothera (Onagraceae) has the most naturalized species (10), followed by Amaranthus (Amaranthaceae) (9), Euphorbia (Euphorbiaceae) (8), Crotalaria (Fabaceae) (7), and Senna (Fabaceae) (5) (Fig. 1b). Melilotus has the largest percentage (20\%) of naturalized species in China compared with the global number of species in this genus, followed by Cinchona (17\%), Amaranthus (15\%), and Oenothera (8\%). In addition to Oenothera and Amaranthus, both of Melilotus and Cinchona have more than five naturalized species in China.
About $11.4 \%$ of the naturalized species are distributed nationwide (Table 2). The Asteraceae is the dominant family, with 11 naturalized species occurring in all provinces, followed by Fabaceae (6), Amaranthaceae (5), and Poaceae (4).

Most of the naturalized species have had more than one path of introduction, while the route of introduction of only a small portion of the species is unknown About $51 \%$ of the naturalized species were introduced for medicinal purposes, followed by 
Table 2 List of 47 nationally distributed species

\begin{tabular}{|c|c|}
\hline Apiaceae & Phyllanthus niruri $\mathrm{L}$. \\
\hline Coriandrum sativum $\mathrm{L}$. & Ricinus communis $\mathrm{L}$. \\
\hline Amaranthaceae & Fabaceae \\
\hline Alternanthera pungens Kunth & Medicago lupulina $\mathrm{L}$. \\
\hline Alternanthera sessilis (L.) R. Br. ex DC. & Medicago sativa $\mathrm{L}$. \\
\hline Amaranthus albus L. & Melilotus albus Medik. \\
\hline Celosia argentea $\mathrm{L}$. & Trifolium pratense $\mathrm{L}$. \\
\hline Gomphrena globosa L. & Trifolium repens $\mathrm{L}$. \\
\hline Asteraceae & Vicia sativa $\mathrm{L}$. \\
\hline Ageratum houstonianum Mill. & Malvaceae \\
\hline Amberboa moschata (L.) DC. & Hibiscus trionum $\mathrm{L}$. \\
\hline Ambrosia artemisiifolia $\mathrm{L}$. & Onagraceae \\
\hline Conyza canadensis (L.) Cronq. & Oenothera odorata Jacq. \\
\hline Coreopsis grandiflora Hogg. ex Sweet & Oxalidaceae \\
\hline Coreopsis tinctoria Nutt. & Oxalis corymbosa DC. \\
\hline Eupatorium coelestinum $\mathrm{L}$. & Poaceae \\
\hline Iva xanthifolia Nutt. & Coix lacryma-jobi $\mathrm{L}$. \\
\hline Lagascea mollis Cass. & Phalaris canariensis $\mathrm{L}$. \\
\hline Praxelis clematidea R. M. King \& H. Rob. & Setaria glauca (L.) P. Beauv. \\
\hline Sanvitalia procumbens Lam. & Setaria viridis (L.) P. Beauv. \\
\hline Tagetes patula $\mathrm{L}$. & Polygonaceae \\
\hline Capparaceae & Polygonum aviculare $\mathrm{L}$. \\
\hline Cleome burmannii Wight \& Arn. & Pontederiaceae \\
\hline Caryophyllaceae & Eichhornia crassipes (Mart.) Solms \\
\hline Saponaria officinalis $\mathrm{L}$. & Portulacaceae \\
\hline Convolvulaceae & Talinum paniculatum (Jacq.) Gaertn. \\
\hline Calonyction muricatum (L.) G.. Don & Solanaceae \\
\hline Ipomoea alba $\mathrm{L}$. & Capsicum annuum $\mathrm{L}$. \\
\hline Ipomoea purpurea (L.) Roth & Datura stramonium L. \\
\hline Cyperaceae & Nicandra physaloides (L.) Gaertn. \\
\hline $\begin{array}{l}\text { Eleocharis valleculosa Ohwi f. setosa (Ohwi) Kitag. } \\
\text { Euphorbiaceae }\end{array}$ & $\begin{array}{l}\text { Solanum pseudocapsicum L. var. diflorum } \\
\text { (Vell.) Bitter }\end{array}$ \\
\hline Phyllanthus amarus Schumach. \& Thonn. & \\
\hline
\end{tabular}

ornamentals $(41 \%)$, crops $(34 \%)$, cultivation (18\%), and timbering $(2 \%)$.

As for the origins of the naturalized species, the Americas have been the largest contributors (58\%), followed by Europe (15\%), Asia (12\%), and Africa (9\%). Species from Eurasia, Australia, and those with a general notion of origin represent only approximately $6 \%$ of the naturalized flora in China. Tropical areas of the Americas, Asia, and Africa were especially important sources $(64 \%)$. Europe represents the single most important donor of temperate species naturalized in China.
Local biodiversity, anthropogenic and climatic factors are significantly correlated with the index of invasion province-wide and region-wide (Fig. 2; Table 3). The number of naturalized species was significantly exponentially correlated to local biodiversity (Fig. 2). Total length of transportation, which is positively significantly correlated to demography, is the only factor significantly correlated to the index of invasion region-wide. Annual highest temperature and temperature difference are significantly correlated to the index of invasion province-wide and region-wide. 


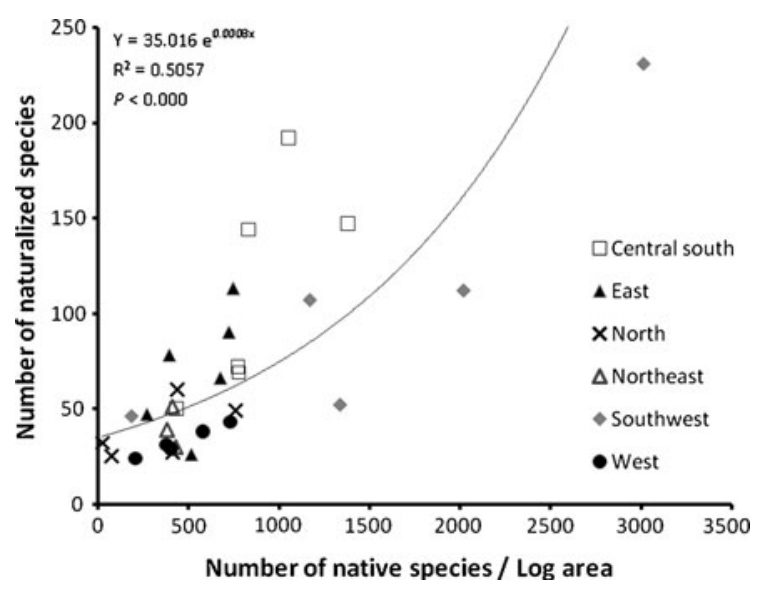

Fig. 2 Regression and curve fitting analysis of naturalized species number to the number of native species per log area. Each point presented a province, and the shapes of data points are designated according to their respective regions

Table 3 Multiple regression analysis of invasion index to anthropogenic and climate factors in regional and provincial scales

\begin{tabular}{|c|c|c|c|c|}
\hline \multirow[t]{2}{*}{ Predictor variable } & \multicolumn{2}{|l|}{ Regional } & \multicolumn{2}{|c|}{ Provincial } \\
\hline & Beta & $P$ & Beta & $P$ \\
\hline \multicolumn{5}{|l|}{ Anthropogenic factors ${ }^{\mathrm{a}}$} \\
\hline Transportation distance & $1.171^{*}$ & 0.023 & - & - \\
\hline Log area & -0.059 & 0.736 & - & - \\
\hline Tourist & -0.279 & 0.337 & - & - \\
\hline \multicolumn{5}{|l|}{ Climate factors ${ }^{\mathrm{b}, \mathrm{c}}$} \\
\hline Average temperature & -0.918 & 0.102 & -0.386 & 0.256 \\
\hline Highest temperature & $0.453 *$ & 0.052 & 0.200 & 0.176 \\
\hline Precipitation & 0.855 & 0.103 & 0.246 & 0.385 \\
\hline Temperature difference & $-0.838 *$ & 0.040 & $-0.902 *$ & 0.000 \\
\hline
\end{tabular}

Beta represents the adjusted correlation coefficients. (* $P<0.05$ )

a Anthropogenic factors in regional scale: $F_{(3,2)}=27.439$, $P=0.035$, Adjusted $R^{2}=0.94$ )

b Climate factors in regional scale: $\left(F_{(4,1)}=281.202\right.$, $P=0.045$, Adjusted $R^{2}=0.996$ )

c Climate factors in provincial scale: $\left(F_{(4,25)}=12.59\right.$, $P=0.000$, Adjusted $R^{2}=0.651$ )

\section{Discussion}

In consideration of the size of the area and the native flora, our intensive efforts only represented a relatively small fraction of the plant invasions in China (Table 1, Appendix; 420 naturalized species) compared to other areas of the world (Mehrhoff 2000,
Enomoto 1999, Wu et al. submitted). The naturalized flora may be as much as five times larger than that compiled in this study according to tens-rules (Williamson and Fitter 1996) and previous estimations of invasive species in China (Liu et al. 2006; Ding et al. 2008; Weber and Li 2008a, b). However, the resolution is not able to be improved due to the quality of taxonomical reports/documents. Although the Flora of China has been comprehensively compiled and the e-flora of China has been underconstruction, naturalization status of introduce and cultivated were hardly stated. The naturalized flora may be seriously underestimated due to unclear statements of naturalization status of cultivated/ introduced species. However, the general patterns of plant invasions in China could still be accessed by our study since the attentions of plant invasions seem to be even across taxonomic groups and geographical regions.

The composition of the dominant naturalized families and genera implied partially their sizes worldwide (Heywood 1989), and their climatic properties. While naturalized species can be placed in 84 families (Table 1), $45 \%$ of them are from only three families, Asteraceae, Poaceae and Fabaceae (Fig. 1a), the major contributors to the alien floras in many regions of Asia (Wu et al. 2004a, b; Zerbe et al. 2004) and of the world (Pyšek 1998). Nevertheless, other important families of the naturalized flora varied slightly in different regions of the world, probably in response to differences of climate in a particular area. Integrated with the fact that a remarkable proportion of naturalized species originated in the tropics, plant invasions in China confirm the assumption that species adapt better to new land where the climate is similar to their homeland (Corlett 1988, 1992). Convolvulaceae, Euphorbiaceae, and Amaranthaceae are considered to be tropical or warm temperate families, and Brassicaceae and Caryophyllaceae are more adapted to cooler climates, such as temperate China, due to similar climates in their home range (Weber 1997; Vilà and Muñoz 1999; Pyšek et al. 2002; Rouget and Richardson 2003). Over representation of Cactaceae species may be the case as well. The xeric environments, such as the extensive deserts in the North (Nei Mongol), in the West (Xinjiang), and in dry, hot valleys of the Southwest (Sichuan, Yunnan) provide suitable habitats for Cactaceae. Based on the ratio of 
naturalized species to global species per family, the importance of Euphorbiaceae and Cactaceae emerged. Each of these families has around 650750 species, but the over-representation of these two families suggests that they are especially successful in China (Rejmánek et al. 1991) and deserve further attention.

In contrast, the species numbers of the dominant genera did not completely coincide with the size of their world species pools or the importance of their respective families in the naturalized flora in China. Although Crotalaria and Euphorbia have hundreds of species worldwide, Oenothera and Amaranthus are only intermediate in size, with 124 and 60 species respectively (Mabberley 1997). No particular pattern was found between the worldwide size of the species pool and the dominancy of naturalized genera. Overrepresentation of Cinchona and Melilotus, however, may deserve deliberate investigation due to their high values in the ratio of naturalized versus global species number per genus.

The high percentage $(84 \%)$ of newly naturalized genera in the flora seems to support Darwin's idea that exotic floras are gaining disproportionately more new genera than new species (Darwin 1859). The idea is that species in exotic genera may be exposed to less competition when they do not have to interact with native congeners. This assumption is also supported by the high percentage (52\%) of genera with only one naturalized species. A similar pattern is not shown for naturalized families. Only $16 \%$ of the families have less than five naturalized species, and only $10 \%$ of the naturalized families are new to China. Darwin's hypothesis has also been supported by data from California (Rejmánek 1998), but not from islands (Daehler 2001; Duncan and Williams 2002). However, we do not know whether this is simply a result of random selection.

Life forms and habits of most naturalized species coincided with the features of the families and genera that have the most naturalized species (Table 1; Fig. 1a, b). For example, Brassicaceae, Fabaceae, Asteraceae and Poaceae are mainly composed of therophytes, phanerophytes, chamaephytes, and hemicryptophytes. The large number of perennial species (phanerophytes, chamaephytes, and hemicryptophytes) in China may be an indicator of serious environmental impact in the future (Huang et al. 2009).
The remarkable percentage of naturalized species with medicinal properties may be the result of China's long history of use of herbal medicines and the definition of medicinal plants. In China, herbal medicines have been used for thousand years, and the application of herbal medicines is highly popular and influential even today. Furthermore, almost every plant can be used to improve or supplement human health more or less according to ancient references (Li 1578; Boym 1656). It appears that the proportion of naturalized species with so-called medicinal properties may be magnified. Although medicinal species are important to human society and have been introduced in many places (Maheshwari and Paul 1975; Klemow et al. 2002), only a relatively small proportion of them are naturalized or invasive (Austin 2000; Weber 2003).

The significant correlations between plant invasions and local biodiversity as well as climates may imply that suitable environment for growth is a key factor determining the biodiversity of native and naturalized floras (Figs. 2, 3). Mesic environment of southern China accommodated most of native species; however, the high biodiversity did not perform as resistance to plant invasions in these areas. Exponentially increased number of naturalized species along native number per log area may be a result of unfulfilled niches and habitat limitation. Disturbances may be responsible as well; however, further information is not currently available for better understandings. Close and significant relationship between invasion index and climatic factors (Table 2), such as annual average temperature, annual lowest temperature, temperature difference, and annual average precipitation, reinforces this descending trend of plant invasion across climatic zones, which symbolize available growth seasons and conditions. This pattern is also very similar to that of altitudinal gradients (Lingua et al. 2008; MallenCooper and Pickering 2008). Habitat limitation seems to be responsible for the diversity of both of naturalized and native species along horizontal climatic gradients of temperature and precipitation. Furthermore, the decrease in sizes of the global species pool from the tropics to the Arctic/Antarctic may indicate the decreasing number of species available for introduction (Barthlott et al. 1996; Kier et al. 2005). We do not, however, have an explanation for why tropical American species were so copiously 
Fig. 3 Climatic zones and intensity of plant invasions in China. Black lines indicate provincial boundaries. Numbers are an index of number of casual and naturalized species/log (area of a particular region in $\mathrm{km}^{2}$; Vitousek et al. 1997) in each province. Colors designate different climatic zones across China

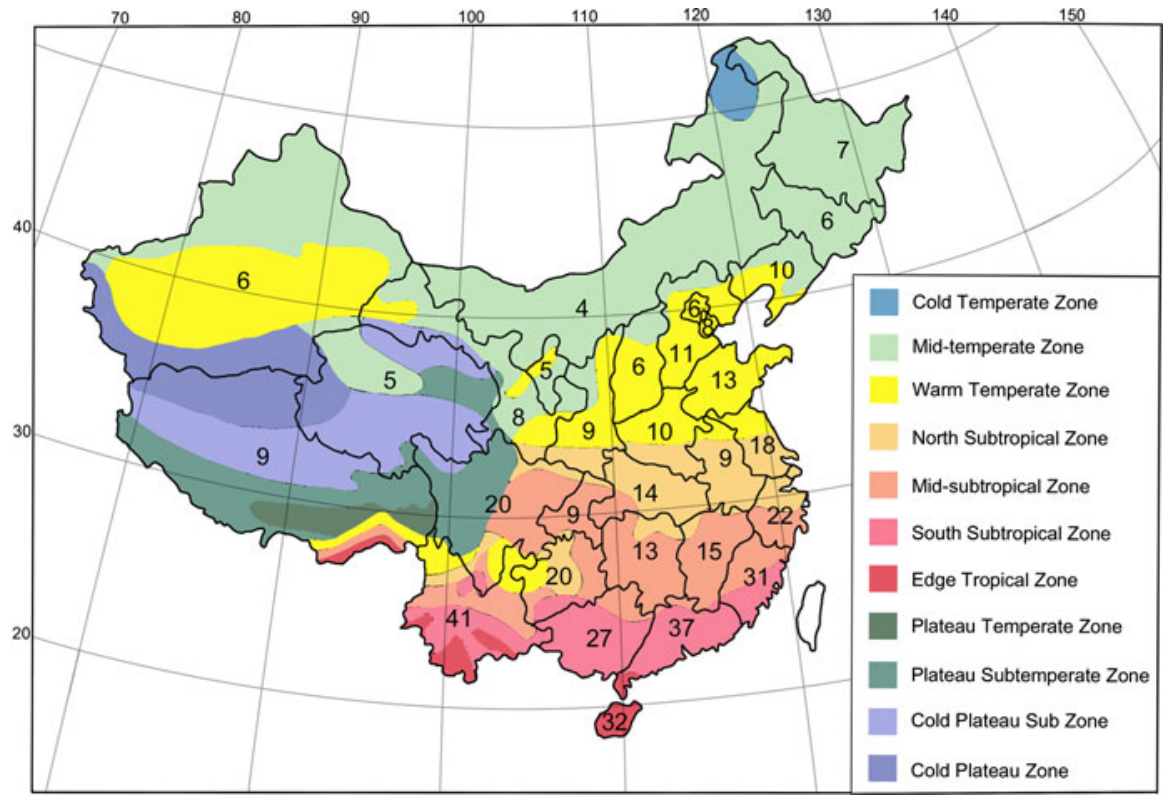

represented, further studies are urgently needed for a better understanding of plant invasions in China.

Although only few anthropogenic factors are significantly correlated with the index of invasion, the effects of the local economy on plant invasions are indisputable (Table 3). Significant correlations of total length of transportation, which was highly correlated to demography, implies the population size (data not shown) and moving efforts of plant invasions in the regional scale (Gelbard and Belnap 2003; Liu et al. 2005). It was a surprise quantity of freight, extent of freight turnover, and number of international tourists showed no contributions to plant invasions in China. Perhaps latest data were not comprehensive and our analysis did not reflect the impacts of the local economy and development on plant introduction. Nevertheless, with an increase in transportation length facilitated by booming economy, the relationship with plant invasions should be monitored to prevent further impacts (Dong et al. 2008).

Although China's naturalized flora is relatively small, the proportion species occurring nation-wide (11.4\%) to the total number of naturalized species coincides with the tens rule. Moreover, the taxonomic and biogeographical patterns of plant invasions in China are very similar to patterns in neighboring regions (Corlett 1988; Enomoto 1999; Koh et al. 2000; Wu et al. 2003; Wu et al. 2004a, b). However, the documentation of naturalized species, potential invaders, and the status of introduced species, is still far from sufficient. It is worrisome that knowledge and study on naturalized species, invasive species, and biological invasions is scanty in China. We recommend that extra attention be paid to certain plant families, such as Euphorbiaceae and Cactaceae, while additional studies are required for a few critical genera, such as Cinchona and Melilotus. In conclusion, the above-mentioned close relationship between climate and plant invasions may, furthermore, alert people in the warmer parts of China that extreme care should be given to introducing species.

Acknowledgments We thank Dr. David E. Boufford for improving the writing and offering valuable suggestions on the organization and ideas of this manuscript; Drs. Keping Ma, Lisong Wang and Zhenyu Li from Academia Sinica Beijing to provide acurate numbers of native species in China; two annonomus reviewers to provide valuable comments.

Open Access This article is distributed under the terms of the Creative Commons Attribution Noncommercial License which permits any noncommercial use, distribution, and reproduction in any medium, provided the original author(s) and source are credited.

\section{Appendix}

See Table 4. 


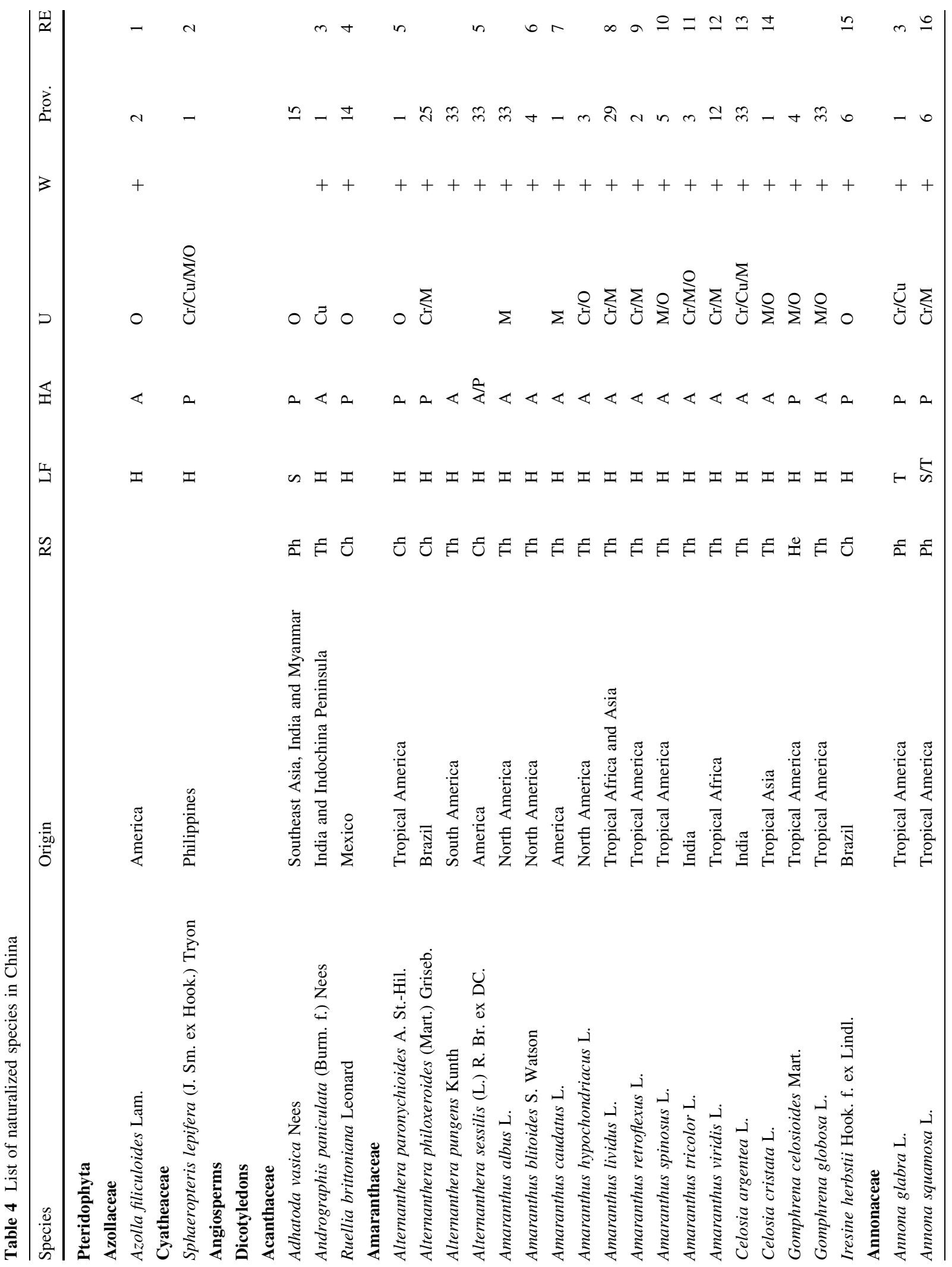




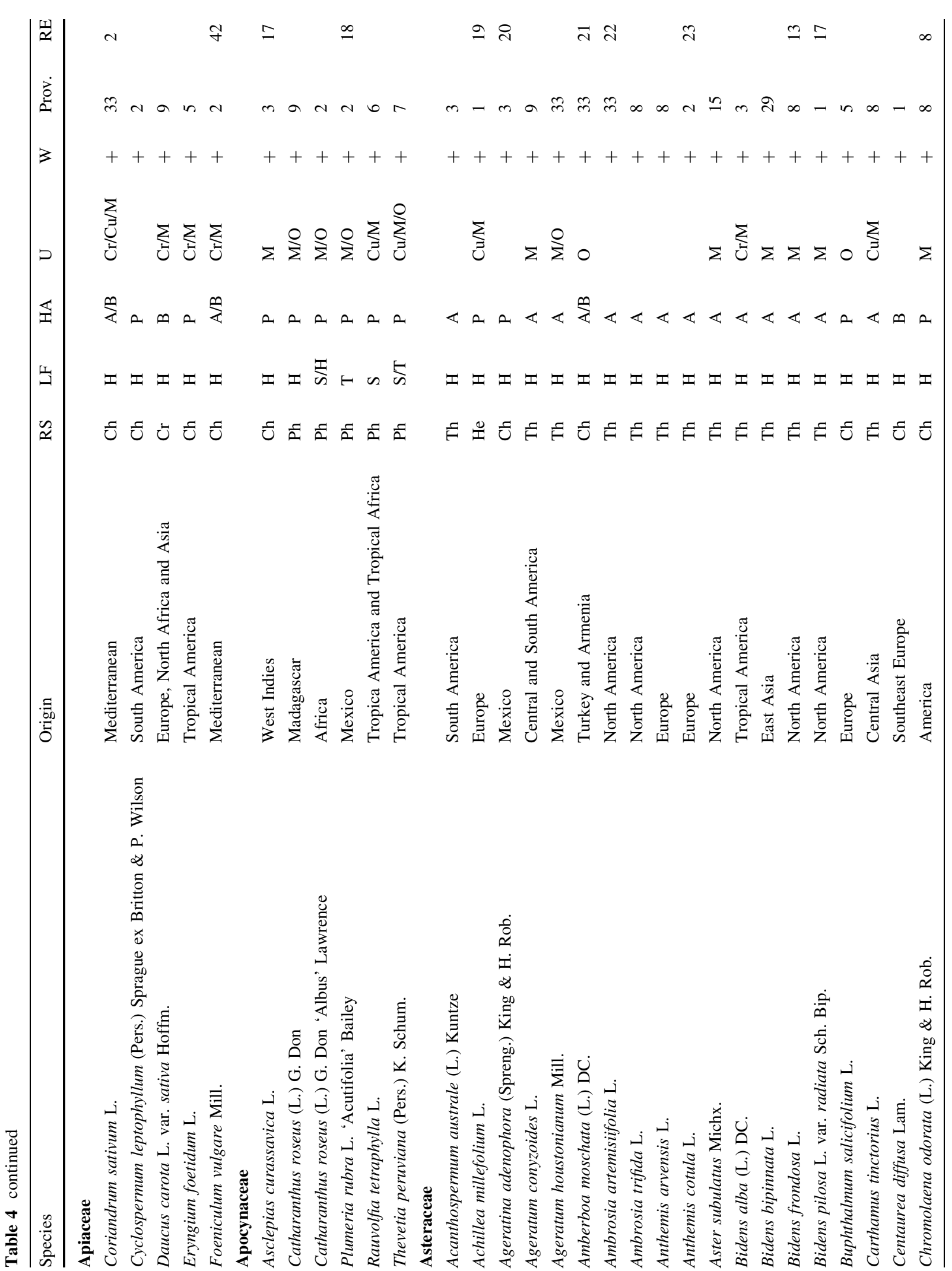




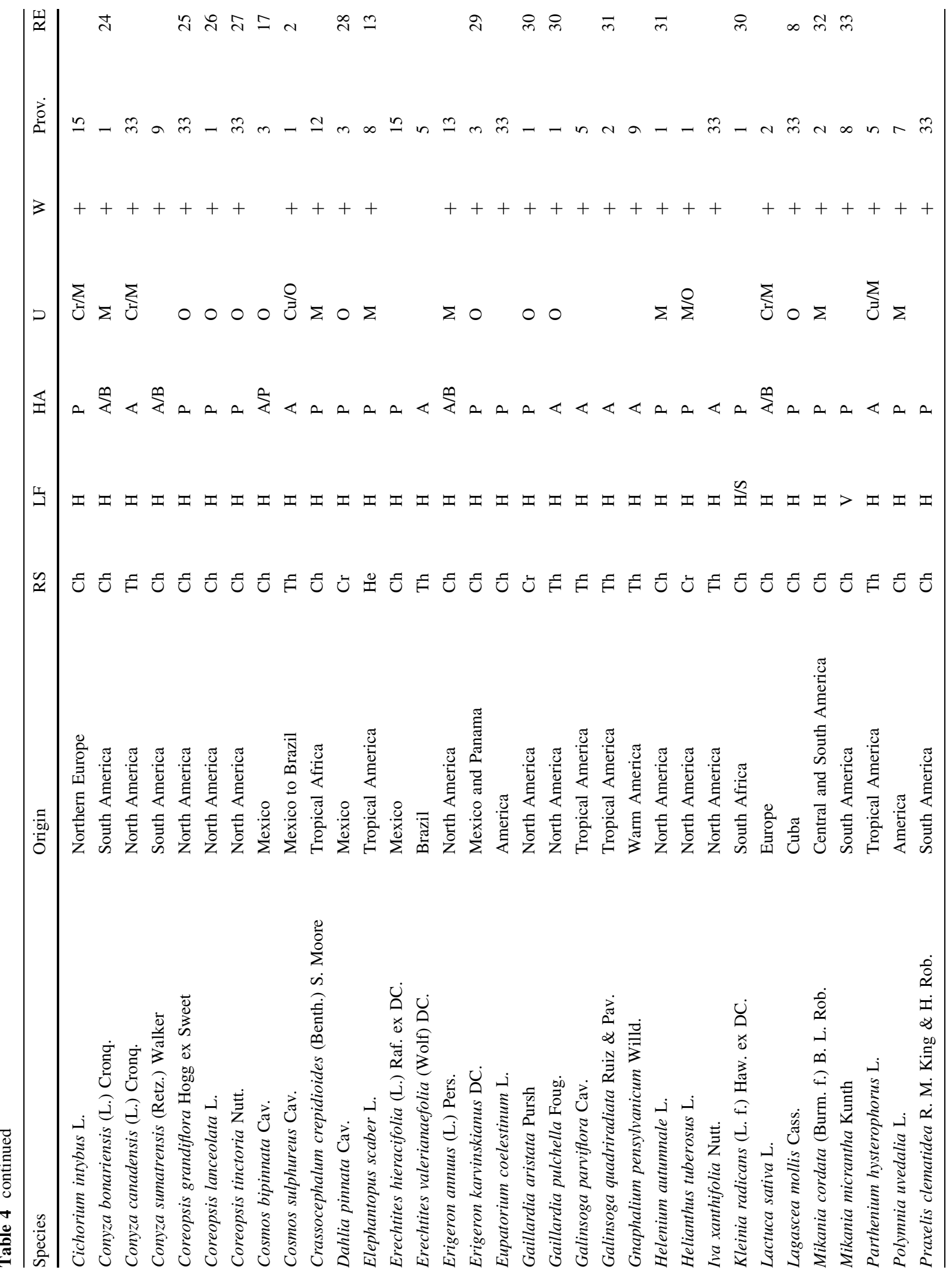




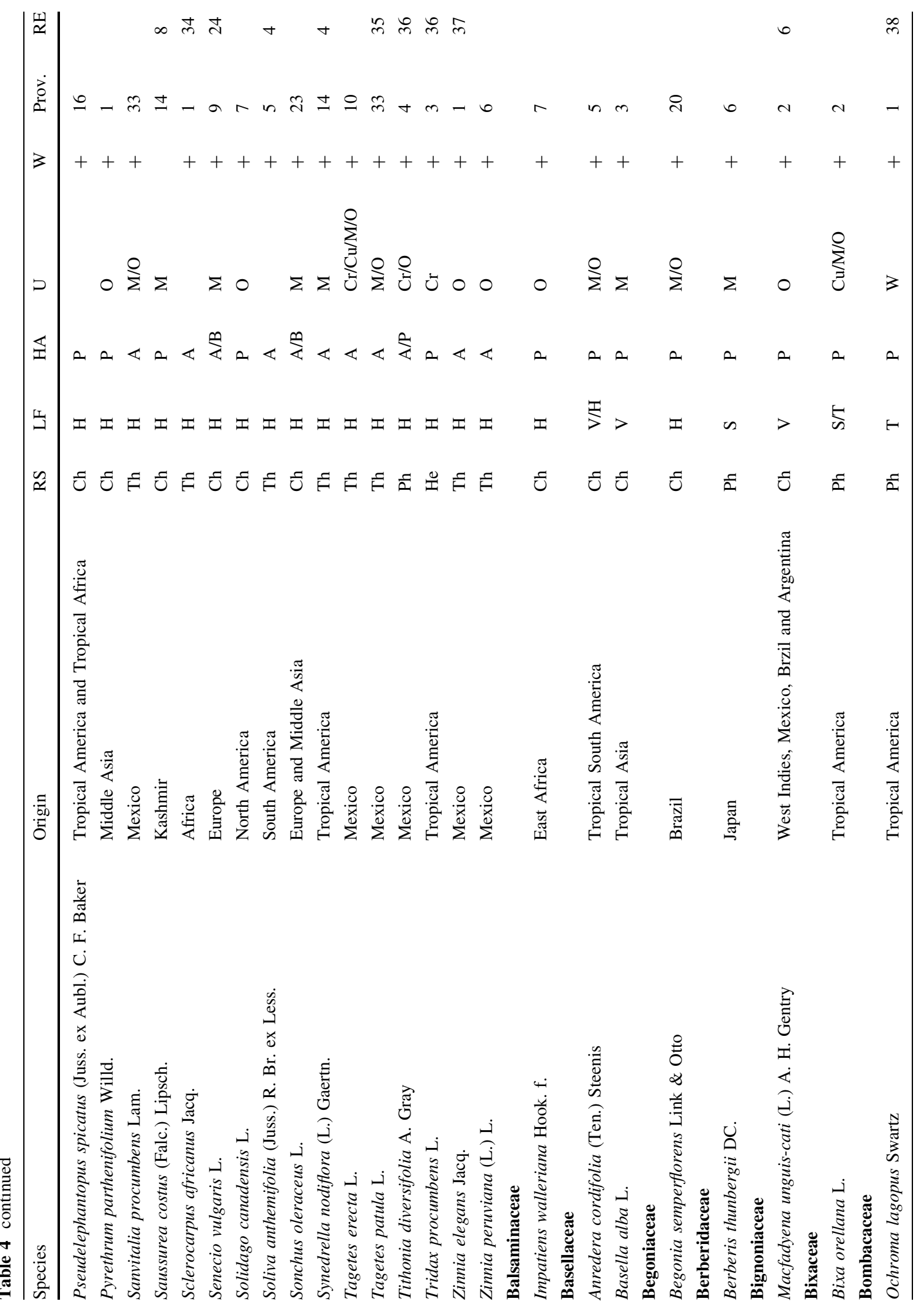




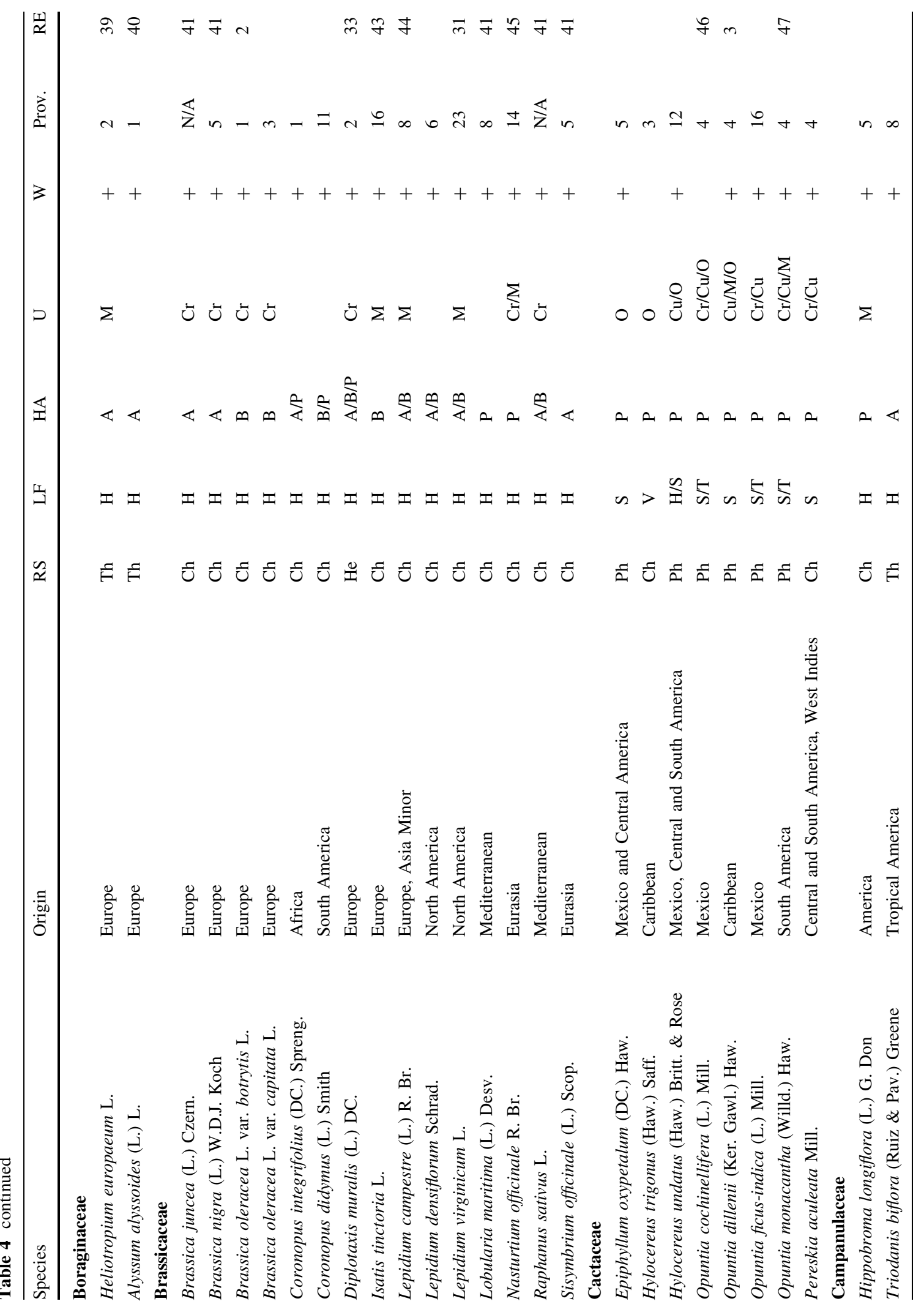


Patterns of plant invasions in China

2193

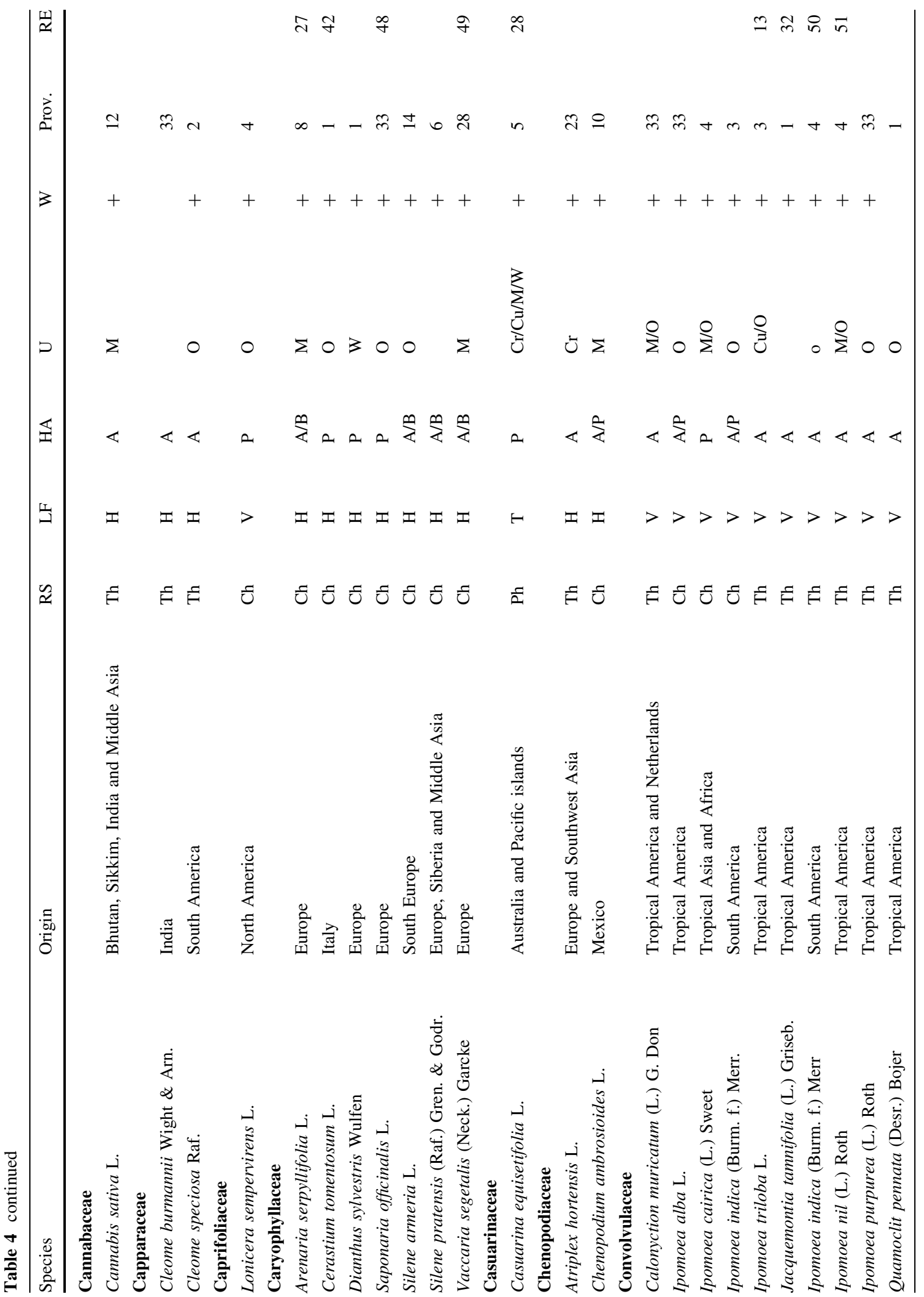

Springer 


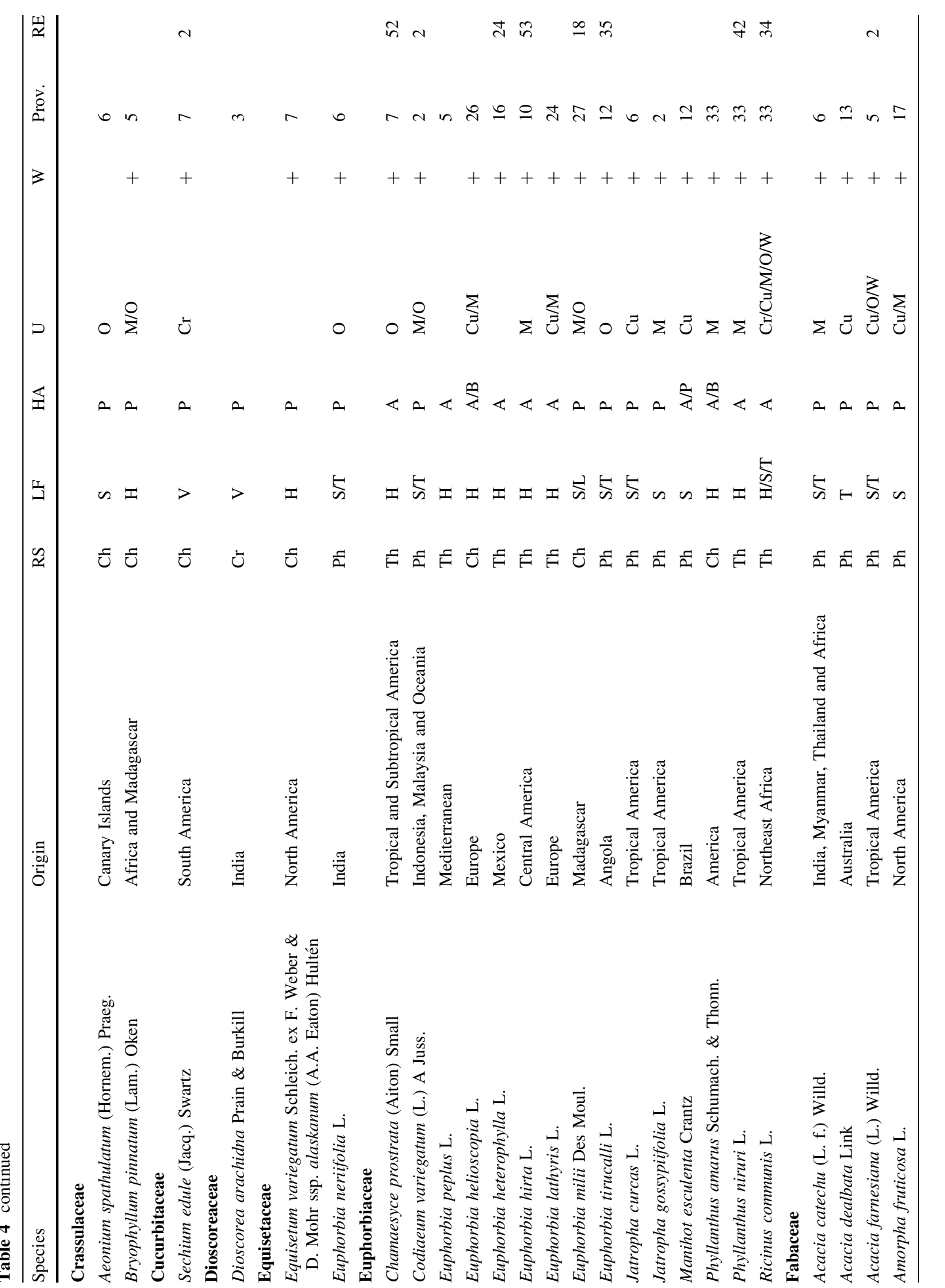




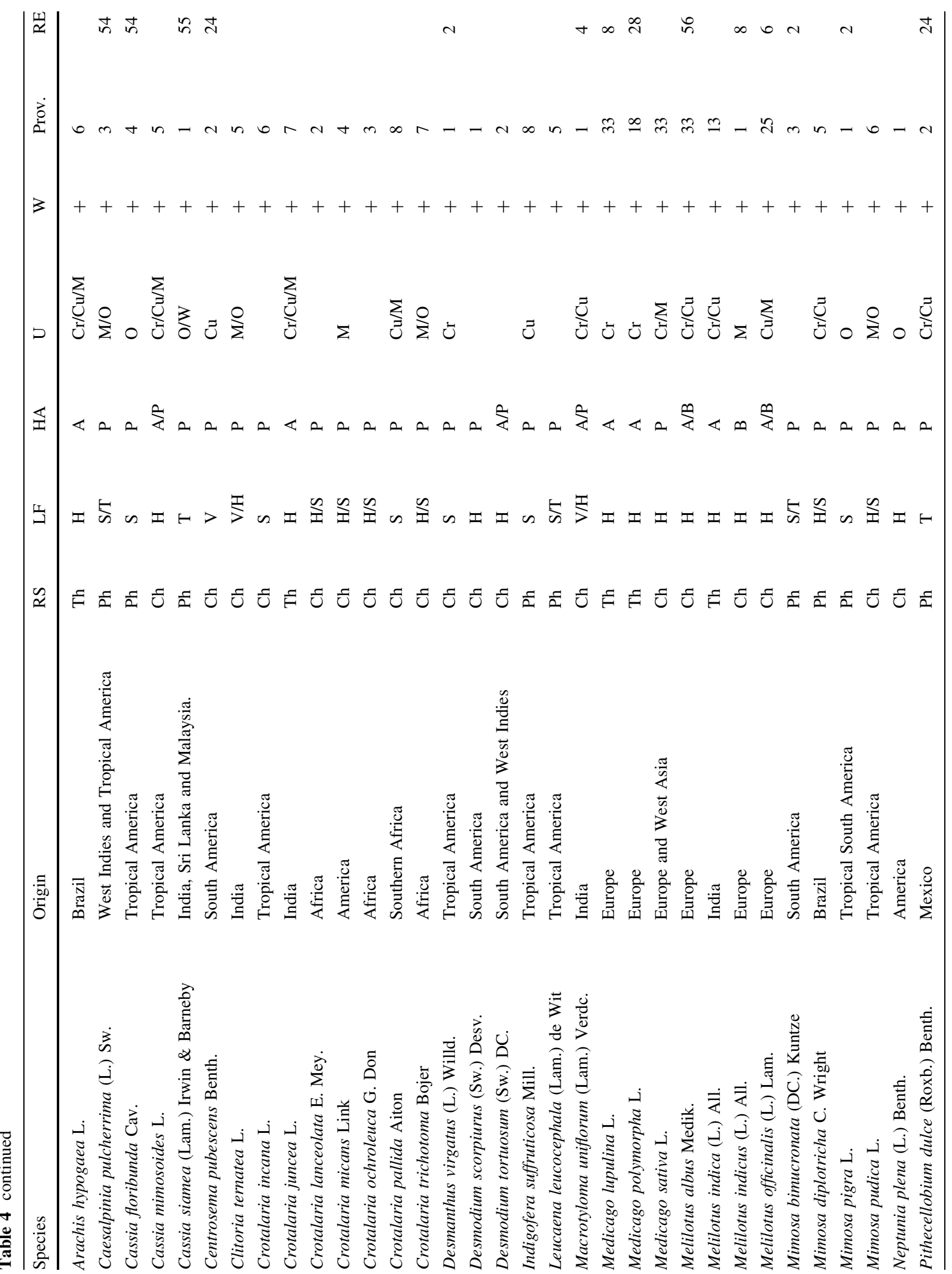




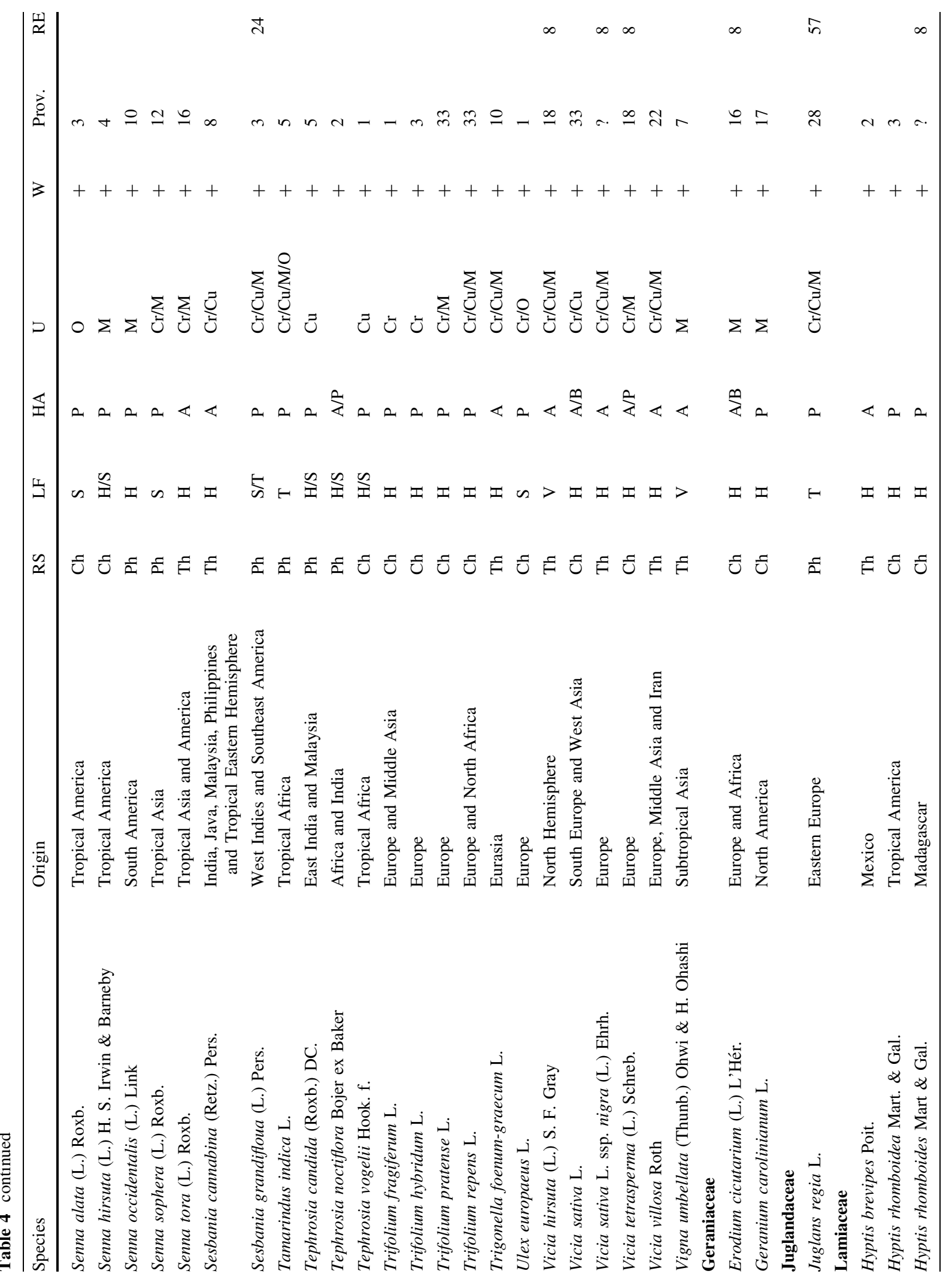


Patterns of plant invasions in China

2197






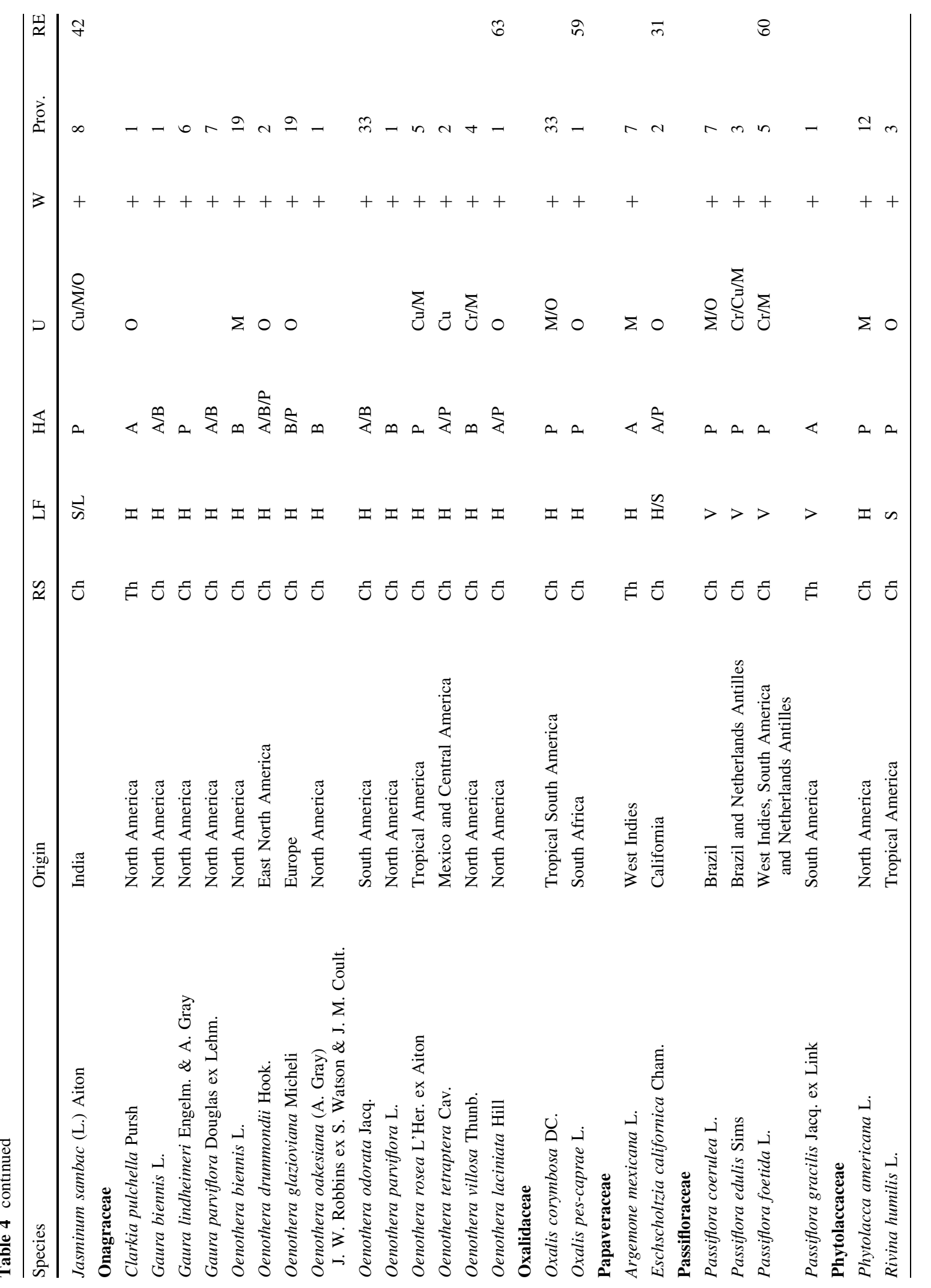









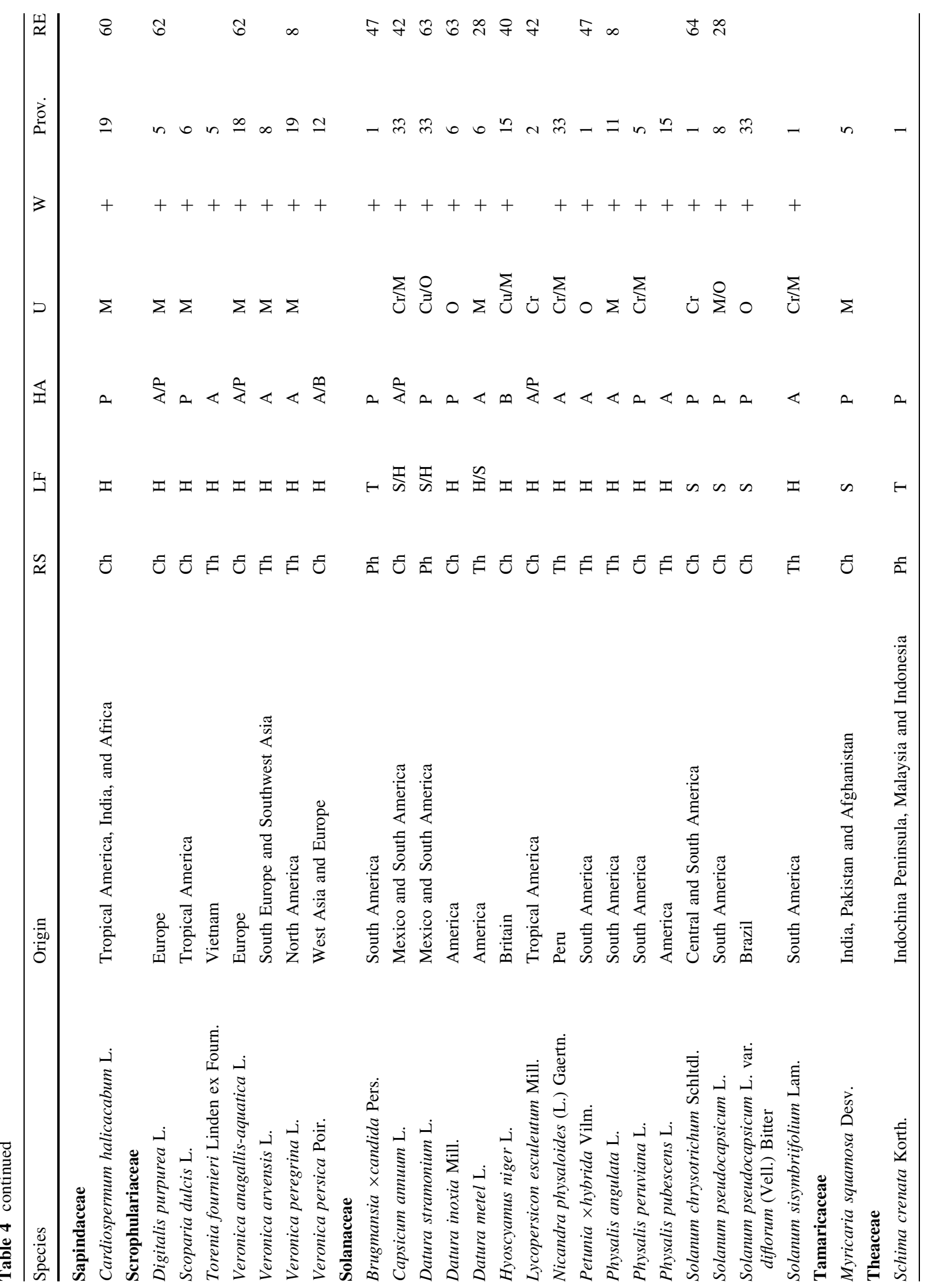









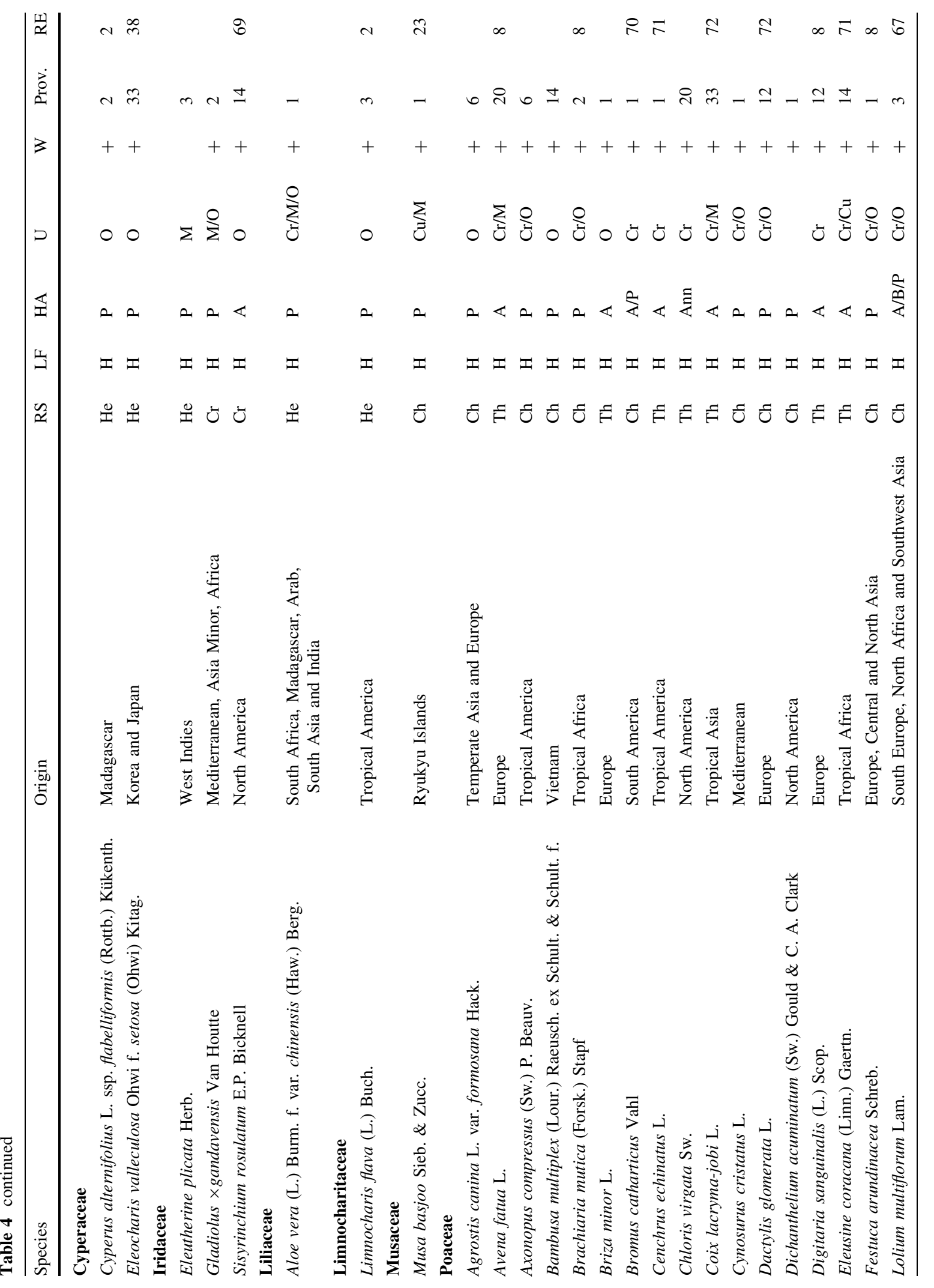




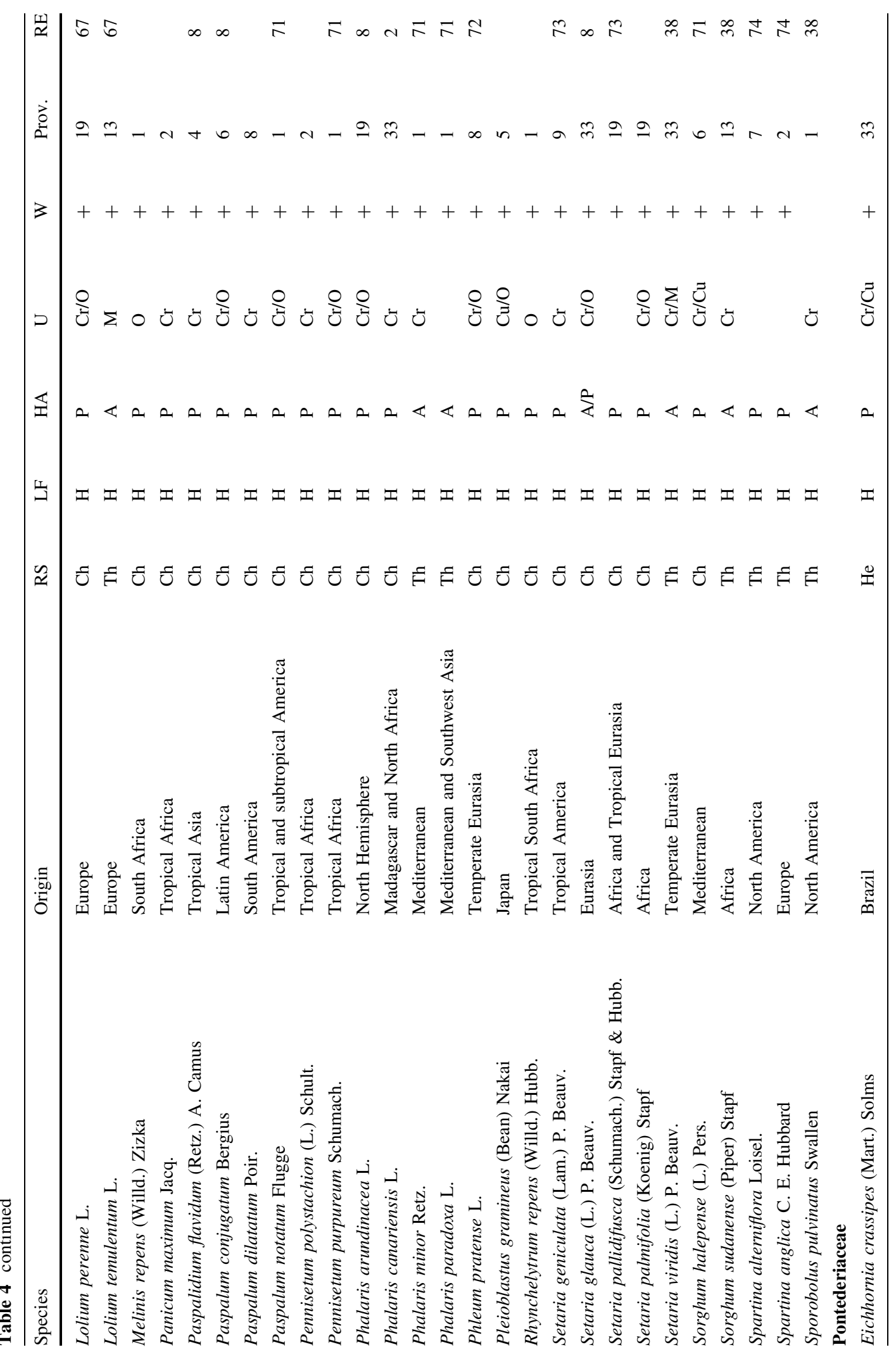









\section{References}

Austin DF (2000) Bindweed (Convolvulus arvensis, Convolvulaceae) in North America: From medicine to menace. J Torrey Bot Soc 127:172-177

Barthlott W, Lauer W, Placke A (1996) Global distribution of species diversity in vascular plants: towards a world map of biodiversity. Erdkunde 50:317-327

Boym M (1656) Flora Sinensis, Vienna, Austria

Cadotte MW, Murray BR, Lovett-Doust J (2006) Ecological patterns and biological invasions: using regional species inventories in macroecology. Bio Invasions 6:809-821

Chytrý M, Maskell LC, Pino J, Pyšek P, Vilà M, Font X, Smart SM (2008) Habitat invasions by alien plants: a quantitative comparison among Mediterranean, subcontinental and oceanic regions of Europe. J Appl Ecol 45:448-458

Corlett RT (1988) The naturalized flora of Singapore. J Biogeo 15:657-663

Corlett RT (1992) The naturalized flora of Hong Kong: a comparison with Singapore. J Biogeo 19:421-430

Daehler C (2001) Darwin's naturalization hypothesis revisited. Am Nat 158:324-330

Dalmazzone S (2000) Economic factors affecting vulnerability to biological invasions. In: Perrings $\mathrm{C}$, Williamson $\mathrm{M}$, Dalmazzone $\mathrm{S}$ (eds) The economics of biological invasions. Edward Elgar Publishing, Cheltenham

Darwin C (1859) On the origin of species. J. Murray, London

Ding J, Mack RN, Lu P, Ren M, Huang H (2008) China's booming economy is sparking and accelerating biological invasions. BioSci 58:317-324

Dong SK, Cui BS, Yang ZF, Liu SL, Liu J, Ding ZK, Zhu JJ (2008) The role of road distribution in the dispersal and spread of Ageratina adenophora along the Dian-Myanmar International Road. Weed Res 48:282-288

Duncan RP, Williams PA (2002) Darwin's naturalization hypothesis challenged. Nature 417:608-609

Enomoto T (1999) Naturalized weeds from foreign countries into Japan. In: Yano E, Matsuo K, Shiyomi M, Andow DA (eds) Biological invasions of ecosystem by pests and beneficial organisms. National Institute of Agro-Environmental Science, Tsukuba, pp 1-14

Gelbard JL, Belnap J (2003) Roads as conduits for exotic plant invasions in a semiarid landscape. Conser Bio 17:420-432

Heywood VH (1989) Patterns, extents, and modes of invasions by terrestrial plants. In: Drake JA, Mooney HA, di Castri F, Groves RH, Kruger FJ, Rejmánek M, Williamson M (eds) Biological invasions: a global perspective, scope 37. John Wiley, New York, pp 31-60

Huang QQ, Wu JJ, Bai YY, Zhou L, Wang GX (2009) Identifying the most noxious invasive plants in China: role of geographical origin, life form and means of introduction. Biodivers Conserv 18:305-316

Jenkins PT (1996) Free trade and exotic species introductions. Conser Bio 10:300-302

Kier G, Mutke J, Dinerstein E, Ricketts TH, Kuper W, Kreft H, Barthlott W (2005) Global patterns of plant diversity and floristic knowledge. J Biogeo 32:1107-1116

Klemow KM, Clements DR, Threadgill PF, Cavers PB (2002) The biology of Canadian weeds. 116. Echium vulgare L. Can J Plant Sci 82:235-248
Kloot PM (1987) The naturalized flora of South Australia 4. Its manner of introduction. J Adelaide Bot Gar 10:223-240

Koh KS, Na JG, Suh MH, Kil JH, Ku YB, Yoon JH, Oh HK (2000) The effects of alien plants on ecosystem and their management (I). The Plant Taxonomic Society of Korea, Korea In Korean

Lake JC, Leishman MR (2004) Invasion success of exotic plants in natural ecosystems: the role of disturbance, plant attributes and freedom from herbivores. Bio Conser 117:215226

Levin JM, D'Antonio CM (2003) Forecasting biological invasions with increasing international trade. Conser Bio $17: 322-326$

Li SZ (1578) Ben Cao Gang Mu (Compendium of Materia Medica), China (In Chinese)

Lingua E, Cherubini P, Motta R, Nola P (2008) Spatial structure along an altitudinal gradient in the Italian central Alps suggests competition and facilitation among coniferous species. J Veg Sci 19:425-436

Liu J, Liang SC, Liu FH, Wang RQ, Dong M (2005) Invasive alien plant species in China: regional distribution patterns. Diver Distr 11:341-347

Liu J, Dong M, Miao SL, Zhen YL, Song MH, Wang RQ (2006) Invasive alien plants in China: role of clonality and geographical origin. Bio invasions 8:1461-1470

Mabberley DJ (1997) The plant—book. A portable dictionary of the vascular plants. Cambridge University Press, UK

Mack RN (2003) Plant naturalizations and invasions in the eastern United States: 1634-1860. Ann Missouri Bot Gar 90:77-90

Mack RN, Erneberg M (2002) The United States naturalized flora: largely the product of deliberate introductions. Ann Missouri Bot Gar 89:176-189

Maheshwari JK, Paul SR (1975) The exotic flora of Ranchi India. J Bombay Nat Hist Soc 72:158-188

Mallen-Cooper J, Pickering CM (2008) Linear declines in exotic and native plant species richness along an increasing altitudinal gradient in the Snowy Mountains, Australia. Aus Ecol 33:684-690

McNeely JA (2000) The great reshuffling: how alien species help feed the global economy. In: Sandlund OT, Schei PJ, Viken $\AA$ (eds) Invasive species and biodiversity management. Kluwer, Dordrecht

Mehrhoff LJ (2000) Immigration and expansion of the New England Flora. Rhodora 102:280-298

Mueller-Dombois D, Ellenberg H (1974) Aims and methods of vegetation ecology. John Wiley, New York

Pyšek P (1998) Is there a taxonomic pattern to plant invasions? Oikos 82:282-294

Pyšek P, Prach K (2003) Research into plant invasions in the Czech Republic: history and focus. Bio Invasion 5:337348

Pyšek P, Sádlo J, Mandák B (2002) Catalogue of alien plants of the Czech Republic. Preslia Praha 74:97-186

Pyšek P, Richardson DM, Rejmánek M, Webster GL, Williamson M, Kirschner J (2004) Alien plants in checklists and floras: towards better communication between taxonomists and ecologists. Taxon 53:131-143

Rejmánek M (1998) Invasive plants and invasible ecosystems. In: Sandlund OT, Schei PJ, Viken $\AA$ (eds) Invasive 
species and biodiversity managementp. Kluwer, Dordrecht, pp 79-102

Rejmánek M, Richardson DM (1996) What attributes make some plant species more invasive? Ecology 77:1655-1661

Rejmánek M, Thomsen CD, Peters ID (1991) Invasive vascular plants of California. In: Groves RH, Di Castri F (eds) Biogeography of mediterranean invasions. Cambridge University Press, Cambridge, pp 81-101

Richardson DM, Pyšek P, Rejmánek M, Barbour MG, Panetta FD, West CJ (2000) Naturalization and invasion of alien plants: concepts and definitions. Diver Distr 6:93-107

Rouget M, Richardson DM (2003) Inferring process from pattern in plant invasions: a semimechanistic model incorporating propagule pressure and environmental factors. Am Nat 162:713-724

Ruiz GM, Carlton JT (2003) Global pathways of biotic invasions. Island Press, Washington

Shigesada N, Kawasaki K (1997) Invasion of alien species. Biological Invasions: theory and practice. Oxford University Press, New York

Valladares-Padua C (2006) Importance of knowledge-intensive economic development to conservation of biodiversity in developing countries. Conser Biology 20:700-701

Van der Wal R, Truscott AM, Pearce ISK, Cole L, Harris MP, Sarah W (2008) Multiple anthropogenic changes cause biodiversity loss through plant invasion. Global Change Bio 14:1428-1436

Vilà M, Muñoz I (1999) Patterns and correlates of exotic and endemic plant taxa in the Balearic Islands. Ecologia Mediterranea 25:153-161
Vitousek PM, D'Antonio CM, Loope LL, Rejmánek M, Westbrooks R (1997) Introduced species: a significant components of human-caused global change. New Zea J Ecol 21:1-16

Weber EF (1997) The alien flora of Europe: a taxonomic and biogeographic review. J Veg Sci 8:565-572

Weber E (2003) Invasive plant species of the world. A reference guide to environmental weeds. CABI Publishing, UK

Weber E, Li B (2008a) Plant invasions in China: what is to be expected in the wake of economic development? Bioscience 58:437-444

Weber E, Li B (2008b) Invasive alien plants in China: diversity and ecological insights. Biol Invasions 10:1411-1429

Williamson M (1996) Biological invasions. Chapman Hall, London

Williamson M, Fitter A (1996) The varying success of invaders. Ecology 77:1661-1666

Wu SH, Chaw SM, Rejmánek M (2003) Naturalized Fabacease (Leguminosae) species in Taiwan: the first approximation. Bot Bull Acad Sin 44:59-66

Wu SH, Hsieh CH, Rejmánek M (2004a) Catalogue of the naturalized flora of Taiwan. Taiwania 49:16-31

Wu SH, Hsieh CF, Chaw SM, Rejmánek M (2004b) Plant invasions in Taiwan: Insights from the flora of casual and naturalized alien species. Diver Distri 10:349-362

Zerbe S, Choi IK, Kowarik I (2004) Characteristics and habits of non-native plant species in the city of Chonju, southern Korea. Ecol Res 19:91-98 